\title{
“ESTUDAR PARA QUÊ?" OU DA VIDA QUE INSURGE PELAS ESCOLAS
}

\author{
Steferson Zanoni Roseiro ${ }^{\mathrm{i}}$ \\ Nahun Thiaghor Lippaus Pires Gonçalves ${ }^{\mathrm{ii}}$ \\ Nayara Santos Perovano ${ }^{\mathrm{iii}}$
}

\begin{abstract}
Resumo: Os modos de pensar a função da escola são fabuladas entre vidas alienígenas, rebeldias e insurreições. Aqui, a força coletiva potencializa e cria rupturas além dos diagramas do poder e dos currículos traçados. Os autores declaram guerra contra as pedagogiasengenheiras que, por projetarem os futuros, amarram todos os corpos curricularizados ao tempo presente, fabricando as imagens de aluno-ideal. Assim, a escola é apresentada em um paradoxo de educar para o amanhã ao mesmo tempo que limita os futuros compossíveis. Amparada na escrita fabulatória da filosofia de Gilles Deleuze, pensa as rebeldias e insurreições estudantis como o cerne da própria escola. Não há função escolar que não perpasse as vidas de alunas e alunos. Por isso mesmo, a escola é uma luta constante que tenta afirmar a multiplicação da vida.
\end{abstract}

Palavras-chave: Vida alienígena; Rebeldia e insurreição; Fabulação; Função da escola; Alunoideal.

\section{"STUDY FOR WHAT?" OR THE LIFE THAT INSURES BY SCHOOLS}

Abstract: The ways of thinking the school's function are fabled among alien lives, rebellions and insurrections. Here, the collective force potentiates and creates ruptures beyond the power diagrams and the predefined curricula. Authors state against the engeneering-pedagogies that, by projecting the future, enlace the curricularized bodies to the present time, manufactoring the images of ideal-students. Therefore, school is shown as a paradox that educates for tomorrow and, at the same time, limits the compossible futures. Supported by the fabling writing from the philosophy of Gilles Deleuze, it thinks the students' rebellion and insurrection as the school's core. There isnt's a school's function that does not run through the students life. Thus, the school fights constantly to affirm the multiplication of life.

Keywords: Alien's life; Rebellion insurrection; Fabulation; School's function; Ideal-student.

\section{Estudar ou não estudar, eis a questão?}

Escola é lugar de professor, não é? Sabemos que uma verdadeira escola é isso, é aquele espaço em que professoras e professores se reúnem para decidir o que vai ser feito com a educação, com o que vai ser ensinado, como os corpos vão aprender. Sabemos que, numa escola, as pessoas entram e esperam sair de lá mais sabidas, ou, pelo menos, mais conhecedoras das coisas.

Porque, afinal, é para isso que serve a escola. 
Ao longo de toda a nossa vida, fomos instruídos por nossas famílias, pelos mais velhos, pelos professores, pela coordenadora, pela diretora, pelos outros de que, na escola, aprendemos a ser alguém na vida.

A escola, afinal, é quase uma chave para o futuro.

Assim somos levados a acreditar.

Por vezes o professor não acredita, não acredita nos alunos ${ }^{\text {iv }}$, não acredita nas perguntas, não acredita na escola, não acredita no potencial da educação e dos estudantes e faz do processo de ensino e aprendizagem uma tarefa mecânica: ler, copiar e ditar, deveres e mais deveres são colocados na mesma conduta. A descrença é tanta que a rotina pode virar um tédio para ambos, professores e alunos, então nos resta indagar para que fazemos aquilo. "Estudar para quê?", perguntam alunos e professores em um grande vazio mental. A pergunta vaga entre as cadeiras da sala sem rumo, ecoando pelos corredores da escola. Antes fosse um daqueles alunos agitados! Um daqueles que precisa apenas de um "JÁ BASTA!" ou um daqueles gritos mais grossos para que o aluno se aquiete. $\mathrm{O}$ resultado esperado é aquele tipo de aluno que muitos professores sonham: quieto, que só fala quando solicitado, que faz as atividades rapidamente e sem muitas perguntas.

Não. A pergunta "Estudar para quê?" se comporta mais como algo sem resposta, sem conteúdo, sem presença. Ela se alastra justamente por não ter rumo. É a sombra de algo que nos pega desprevenidos a cada vez que conseguimos uma brecha entre uma atividade - já mecanizada - e outra. Paramos o lápis ou a caneta por uns míseros segundos e o vento lá fora sussurra a pergunta para nós.

"Para que você faz isso?".

É. A vida pode debochar dessa cobrança contínua em estudar.

Mas será apenas como chave do futuro que a escola efetivamente existe? Estudar é tão somente mesmo um preparo para o mundo? Uma longa e cansativa preparação para algo que ainda não existe? Afinal, são as crianças apenas protótipos de pessoas que passarão a ser "gente" quando, enfim, saírem da escola? Dizem, inclusive, - aos modos de um sussurro - que a escola forma o cidadão!

Evidentemente, enquanto crianças, elas não são cidadãos! Não habitam esse mundo! Pela lógica da escola que forma em tempos sempre para o "amanhã", certamente, as crianças são alienígenas!

E no mundo dos aliens, existem astronautas, visitantes que, por vezes, especulam aqui e ali como é a vida em outro planeta ou se ela existe. Para todo mau aluno-alienígena existe um 
professor-astronauta. E, no estranhamento entre eles, ambos percebem no outro formas de vida cognoscíveis.

Todavia, tem professor que pega um currículo pronto, a Base Nacional Comum Curricular, por exemplo, e faz dele moradia, um santuário de lógica e sabedoria. Esses são os professores-engenheiros, aqueles que pensam, pensam, pensam e mal conseguem sair de seus projetos. Seus projetos são, afinal, milimetricamente orquestrados.

Assim, ele se alia aos currículos estáticos - documentos curriculares - para elaborar seus projetos-aula. Os professores-engenheiros enxergam tais currículos de modo tão sacro que suas aulas precisam, de forma enfática, proceder estritamente dentro do planejado, que sigam de modo quase religioso os documentos curriculares. Horas e horas de planejamento servemlhes para se aliarem bravamente às habilidades e competências curriculares tão bem definidas nos documentos reguladores! E se algo sai um pouquinho da linha, se algo foge minimamente às suas aulas-projeto, é preciso que tudo volte a seu lugar: "Senta na sua cadeira e faz a atividade!". O professor-engenheiro brada tal ordem e implica, muitas vezes, a tentativa de manter tal controle. Afinal é preciso seguir exatamente todo o passo a passo do que ele planejou para que o aluno aprenda.

Mas será esse o único modo de fazer uma aula? Os planejamentos levam mesmo a uma execução impecável? É mesmo possível executar uma aula? Ou planejamos aulas e depois as colocamos em uma aventura de exploração?

Contraditoriamente a esse modo de conceber e praticar as docências - ou não tão contraditoriamente assim -, tem professor que faz da aula uma bagunça planejada, na qual, sem fugir do currículo, ele apronta junto dos alunos, brinca conversa, ensina e aprende com cada um. Sem fugir do currículo ou, quem sabe, expandindo os sentidos de currículo.

Nossa proposta para essa escrita poderia se resumir a esse ponto: a existência desses professores que produzem aulas em orquestras quase desarmônicas não deveria ser entendida apenas como uma questão de didática, mas talvez uma questão de compreensão dos motivos de estudarmos. Daí nossa insistência na perpetuação da pergunta: estudar para quê?

Do olhar regulador, cheio de limites e com vocação para o ensino do conteúdo, a vida escolar, de alguma forma, serve aos princípios da criticidade e da sabedoria como Saviani (2013) insiste em afirmar. Estamos completamente certos dessa verdade? Porque acabamos produzindo as nossas próprias verdades pedagógicas ao contemplar com uma razão inequívoca toda forma de ensinar e aprender. A função da escola como instituição neste contexto é sacra, pois ao propor que a escola seja a instituição responsável pela constituição do humano, a 
perspectiva da pedagogia histórico-crítica (SAVIANI, 2013) passa a reconhecer o humano privilegiadamente a partir de seu grau de escolarização. Nesse caso, parece que a pergunta "Estudar para quê?" pode ser lida como “Quão humano você quer ser?”, e, nesse caso, a resposta iria definir o quanto alguém deve estudar ou não.

Nesse contexto, a vida humana é reconhecida quando a escola cumpre seu papel.

A vida não escolarizada pareceria, então, apagar-se ou, então, tornar-se outra coisa. Os corpos não escolarizados seriam, talvez, não humanos?

Por isso, propomos esse texto como um diálogo entre os modos de pensar a função da escola. Interessa-nos não fazer um resgaste do que tantos outros autores já escreveram e disseram sobre a escola e seu papel. Sabemos, evidentemente, que não foram poucos que se debruçaram sobre a sentido da escola, sobre quais as finalidades da educação na vida em sociedade. Paulo Freire, Demerval Saviani, Ivan Illich, Lev Vygotsky, Maria Montessori, Miguel Arroyo, Sandra Corazza e outros tantos deram modos diferentes de fazer e pensar a escola. Evidentemente, é impossível fugir dos autores das filosofias da educação. Todavia, propomos aqui outra coisa: se a escola fosse pensada a partir das apostas das crianças, como a escola funcionaria? Qual seria o papel da escola a partir das escritas infantis? Quais seriam os sentidos da escola a partir dos corpos que se sentam para aprender?

Para tanto, valemo-nos do método da fabulação deleuziano para escrever sobre a escola a partir desse lugar que não é nosso. Concordamos com Jorge Larrosa (2014) que é preciso criar, em nossas escritas, um povo que carrega forças para além do diagrama já traçado. Sim, muitos de nós, professoras e professores, dizemos o que queremos com as escolas.

É chegada a hora, então, de fazermos as crianças criarem as suas escolas!

\section{Revoltas estudantis por toda parte!}

Um dia, professoras e professores chegaram à escola e se depararam com um grupo de alunos barrando a entrada. Um bando de pirralhos, melhor dizendo. Um ou outro já tinha barba. Ainda assim, apenas crianças. Dessas pequenas ou não tão pequenas que a gente consegue até empurrar se for preciso.

Mas, ali, era uma legião.

E, dada a força coletiva, não haveria passagem.

- Hoje vocês não passarão - falou uma menina com o peito estufado. 
Não devia ter mais de oito anos, baixinha. Com vozforte, ela falava com todos e por todos. Uma menina que, no meio dos outros, quase sumia. Ali tinha um grupo grande, cheio de ousadia que, decididamente, faria o necessário para impedir a entrada de todos os professores.

- Hoje a escola está fechada para vocês - fala um menino - Se quiserem dar meia-volta e voltarem para casa, pode deixar que a gente coloca presença para todo mundo na pauta. Pode deixar, não vamos dar falta para nenhum de vocês!

Chegar numa escola pode ser um baque!

Imaginamos, diariamente, que ao entrarmos numa escola, veremos alunas e alunos torcendo para dar a hora de irem embora. Costumamos, inclusive, ouvir que aluno não quer nada com nada. Na fala popular, ouvimos um monte de vezes que nosso alunado é relapso, preguiçoso e desinteressado.

E, todavia, o momento de entrada de uma escola pode, também, trazer a força de um desejo de escola.

- O que está acontecendo aqui? - pergunta a diretora, quando finalmente chega à escola e se depara com todos os professores do lado de fora. Só então é que repara o exército de alunos à frente do portão - O que é isso? Por que vocês não entraram ainda? Já passou das 07:00 horas!

- Eles ficaram loucos! - reclama uma professora apontando para os alunos.

- Espera um minutinho que eu vou conversar com eles - a diretora responde.

Ela se aproxima do grupo e, quão logo chega perto, os alunos fecham o círculo.

- Preciso falar com o líder desse grupo. Com quem eu falo?

Uma aluna ri.

- Você vai falar com ninguém então, 'fessora. A gente nem sabe quem começou com essa ideia - responde um menino.

- Se quiser falar com todo mundo, é só levantar a voz-fala uma menina.

- Ou você pode reabrir a rádio da escola e falar por lá. Fica bem mais fácil, não é?

O problema surge.

As forças das docências, quando aliadas ao padrão engenharia de ensino, costumam esperar que os alunos ajam apenas como materiais, isto é, que tenham um mínimo de reação e que atendam às expectativas dos cálculos dispensados para eles. Herdeiros de uma lógica bem comportamentalista, algumas docências acreditam que, se forem adicionadas essas e aquelas condições, obterão um quadro de alterações mínimas da matéria e de suas variantes. 
Enquanto fazem cálculos estruturais, esquecem-se que, para além de matéria, os alunos são imanência. Se os professores-engenheiros esperam que eles se assentem em formas bem delimitadas, que estabeleçam as colunas do alicerce da escola, os alunos, por sua vez, agitamse em movimentos infinitos. É bem verdade, como supunha a filosofia de Gilles Deleuze e Félix Guattari (2011b), que muitos desses movimentos são considerados imperceptíveis. Todavia, nem sempre o são.

Vez ou outra, essas agitações são radicais. Elas irrompem a superfície da estrutura expondo, ali, um fundo infinito que leva os alicerces da engenharia-escolar ao sem-fundo, a uma zona de indistinção onde todos os julgamentos, valores e diretrizes da vida perdem seus limites e tornam-se amorfos.

- Ah, é verdade, não é, 'fessora? - fala outra menina, entrando na conversa sempre multifacetada do grupo que enfrenta a diretora - Você fechou a rádio escolar, né? Já até cedeu o espaço para a banda da escola. Que pena! Como vai conseguir falar com todos nós agora?

Eis, talvez, a primeira tese de escola: alunos não são materiais de obra, não são dobrados para o bel prazer e deleite de professoras e professores. Ao contrário do que disse o presidenteeleito brasileiro em 2019, Jair Messias Bolsonaro, alunas e alunos não são massa de manobra de uns professores sabichões. Diante de algumas paralisações nacionais em prol da educação pública, em 2019, o presidente eleito optou por dizer que alunas e alunos são facilmente governáveis por professores, reafirmando a velha lógica dos professores doutrinadores. Sob tal acusação, nós, nas escolas, rimos descaradamente, fazemos memes e criamos piadas. Antes de tudo, a escola é povoada por corpos carregados de vontades.

E aqui, talvez, o termo vontade tenha a ver com a noção nietzscheana, isto é, com o caráter único que a vida é capaz de produzir. A vontade implica em uma força sempre plural, uma força que só existe quando várias forças se confluem para afirmar infinitude da vida (NIETZSCHE, 2015).

- Sinto muito, diretora - fala um menino bastante conhecido por ela. Ele é, na verdade, seu sobrinho - Mas hoje vocês não vão mesmo passar. Estamos resolutos com isso.

- É isso aí! Eu nem sei o que é resoluto, mas podem cair fora!

Desse modo, talvez, é que a força da vida escolar começa a enfrentar os alicerces da engenharia-pedagógica. Contrariando todas as filosofias da educação que insistem em enxergar a escola em seu papel orientador como única detentora das razões, alunas e alunos questionam, diariamente, as decisões que são tomadas sem seu verdadeiro envolvimento. 
Vimos, em 2016, uma série de ocupações escolares tomarem as escolas públicas em nosso país. Vimos estudantes entrarem numa ocupação e aprenderem a se organizarem de modo coletivo. Vimos alunas e alunos colocarem em conversa temas que, até então, não eram considerados "escolares". Vimos grupos de apoio se organizarem. Vimos pessoas entrarem numa ocupa e saírem de lá fênix e leões, revitalizados, cheios de vontade, de desejo de lutar por possíveis de escolas (ALVIM; RODRIGUES, 2016).

A questão, entretanto, é que a ilusão é tamanha se acreditamos que apenas esses movimentos "grandes" marcam as escolas. Não é preciso que se retirem as merendas das escolas públicas para que alunas e alunos produzam, no coletivo, uma força capaz de sacudir a estrutura das escolas. As questões podem ser de grande peso - a desativação da rádio escolar, uma transferência compulsória injusta de um aluno -, mas também podem ser por questões menores, mais cotidianas. Afinal, qual escola nunca sofreu impactos com as gestões indecorosas que nos afetam? E nós, professoras e professores, tomamos atitudes em defesa a essas ações prejudiciais à escola?

Às vezes tomamos, às vezes não.

Deveras, quando não tomamos, é possível ver um grupo de estudantes insurgir.

Quando as forças pedagógicas incidem em ataques às discências, pode ser que mesmo o mais bobo dos casos anime os corpos a se colocarem em práticas revoltosas de liberdade. Quem sabe, até, não sobre para uma lixeira?

- FERDINANDO LUCAS!!! O QUE É ISSO?

- Ah, professora... Você não me deixou ir ao banheiro, então eu fiz no cantinho, né? Na lixeira...

- Eu não acredito! Já para coordenação! E LEVA A LIXEIRA!

Evidentemente, Ferdinando Lucas foi suspenso por dois dias. Foi em um piscar de olhos! Noutro dia, Verônica Luara se senta na lixeira e Dioneide Valéria, sua melhor amiga, faz barraquinha com uma toalha para ela fazer xixi. Mais duas para a coordenação. A lixeira vai e volta, é lavada várias vezes. Quando dá por si, a professora já mandou seis estudantes para a coordenação, meninas e meninos que, indistintamente, colocaram-se a usar a lixeira como espaço público de rebeldia.

De repente, o coordenador aparece na sala e pergunta:

- E agora? Suspendo todos? Porque se continuar assim, você vai ficar sem aluno na sala.

- Professora! PROFESSORA! PROFESSORAAAAAA ... 
- Que foi Eduardo Alberto? Você não pode esperar um pouco?

- O Zezinho também está fazendo xixi!

- É O QUE? Você??! O mais inteligente da turma me faz uma dessas? O que vocês querem com isso? Qual é o problema de vocês? Vai todo mundo dar uma de Ferdinando Lucas?

Em decorrência dos eventos, tem-se a desconstrução do uno, num coletivo representativo de uma imagem, um rearranjo que surge no imediato, mas esse representativo da obediência dos corpos levada ao limite se espalha em infinitudes e multiplicidades. Descentrada, sem início nem fim, acontece, está ali no meio de tudo, entre espaços e brechas, uma conjunção que tenta abolir o ser - individual e identitário - e flui entre incertezas (DELEUZE; GUATTARI, 2011a). A professora não acredita na revolta de sua turma. Não pode acreditar que até mesmo o Zezinho - o Josefino Oslavo! - entrou em uma onda de ofensas a sua postura. Ela olha para a turma depois que o coordenador sai e não entende. Não percebe que paira na sala, de forma quase densa, um desejo de luta por algo simples: o direito de ir ao banheiro livremente.

A trama segue, os estudantes explicam que não querem perder tempo para ir ao banheiro no recreio, porque querem brincar e o lugar vive lotado nessa hora, sendo impossível de usá-lo. Que várias vezes pediram para ir ao banheiro depois do recreio e a regra institucionalizada e criada para as crianças - e não por elas - é cumprida à risca pela professora-engenheira. E Ferdinando começou algo que eles acharam demais! E eles não iam mais segurar e nem implorar para ir ao banheiro.

A revolta acontece numa turma de $4^{\circ}$ ano. A requisição dos alunos é objetiva: "Queremos ter o direito de ir ao banheiro após o recreio ou você vai ter que suspender todo mundo que fizer xixi na lixeira!". Eles encurralam a professora-engenheira, colocando as normativas em curto-circuito.

Um grupo de alunos-alienígenas insurge, mas aparentemente se instalam pelas escolas uma pandemia de insurgências, que deveras podem ser tão potentes quanto a do vírus COVID19, que se iniciou nas escolas do país em março de 2020. Não pelo fator destrutivo, mas pela disseminação e pelas mutações viáveis que elas assumem, desestruturando o que antes era sólido e concreto, exigindo outras soluções e pensamentos. Se o problema antes era o xixi na lixeira, noutro momento pode ser a afinidade, os sentimentos, as relações entre os corpos, e, por que não, com aquele corpo que na escola é decretado como aluno-problema?

A caixa de e-mail da inspeção da Secretaria de Educação enchia cada vez mais de manifestações/denúncias encaminhadas pela ouvidoria falando sobre injustiça com uma tal de 
Escarlate das Graças. E as manifestações eram tantas que as inspetoras foram à escola tentar entender o que estava acontecendo e quem era a tão famosa Maria das Graças que encheu a caixa de e-mail da Secretaria de Educação com inúmeras demandas.

Ao chegar à escola, de longe, o porteiro já avista duas pessoas saindo do carro da prefeitura. Ele já corre para dentro da escola e imediatamente avisa ao diretor. Ao se aproximarem do portão de entrada o diretor já as recebe.

- O que as trazem aqui? Vieram verificar algum problema? - Disse o diretor, com uma voz preocupada.

- Então, senhor diretor, nós estamos aqui para conversarmos sobre as 33 manifestações que recebemos.

- QUANTAS?!?! - Disse o diretor com espanto.

- Isso mesmo! Trinta e três e todas elas falam de uma aluna chama Maria das Graças do $6^{\circ}$ ano D. Nós gostaríamos de conversar com o senhor, a pedagoga e coordenadora.

Sim, por vezes as rebeldias escolares são tão poderosas que a escola precisa tomar decisões radicais. É a transferência, o remanejamento, a ação no Ministério Público, a suspensão. A escola se vê diante das rebeldias e logo vê que perde o balanço. E, por isso mesmo, não aceitam questionamentos. Partem do princípio de que ela, magnânima, está sempre certa e, por isso mesmo, jamais será interpelada por suas ações.

As forças estudantis, decerto, expõem o que há de mais vil na paixão pelo controle.

- Ah! Essa aluna nos causa muitos problemas! É desinteressada, não gosta de estudar, mas adora tumultuar as aulas. Como ela tinha vários atos indisciplinares, nós resolvemos remanejá-la para turno matutino para observar se de manhã ela fica mais calma.

A conversa, evidentemente, é feita toda em tons acusatórios. Diretor, coordenadora e pedagoga se sentam para falar da Escarlate das Graças como uma aluna radicalmente alienígena. E, para comprovar toda a irresponsabilidade dos alunos, toda a equipe gestora da escola aparece com documentos comprobatórios de toda espécie. Livro de ocorrência, registro de atividades de sala, bilhetes nas agendas, convocações da família, termos de responsabilidade - tudo aparece para atestar a incompatibilidade da aluna para com a função do aluno na escola.

Em meio a conversa, ouviram-se vozes mais exaltadas e logo o diretor se levantou para verificar do que se tratava e ao abrir a porta se deparou com trinta e três alunos plantados na sua frente pedindo para serem ouvidos pelas inspetoras. Como eles eram em muitos, elas resolveram escutá-los no refeitório da escola. 
- Ah! A Escarlate, tia, é muito engraçada e divertida. É uma injustiça mandarem ela pra de manhã.

- Eu gosto muito da Gracinha, um dia ela levou leite condensado para a escola e abriu na aula de português e dividiu com todos. Tudo bem que nem deu tempo de comermos tudo porque a professora logo colocou ela para fora de sala e confiscou a latinha.

- Ela é mó parceira - disse uma outra aluna - Um dia ela levou um pote de creme de cabelo para a gente usar, mas a professora de ciências não gostou muito não e mandou ela para a coordenação.

- Mandaram Escarlate para o turno da manhã falando que ela não queria nada com as coisas, mas isso não é verdade porque ela faz os DV. Tá! Tudo bem que ela não tirava dez, mas dava pra passar. Os professores colocavam ela para fora porque ela era 'mó legal e, às vezes, levava biscoito, pirulito e outras coisas para dividir com geral.

De repente, em meio a tantas defesas, ouve-se o coro que dizia: "NÓS NÃO VAMOS ACEITAR ISSO! QUEREMOS ESCARLATE DE VOLTA!”.

É. Decididamente, uma resposta foi dada de modo bem enfático. Pode até ser que as inspetoras saiam de lá comovidas e façam algo de bom pela Escarlate das Graças. Mas pode ser que não.

Ainda assim, é inegável ver o quanto, nesse movimento, as forças coletivas são movimentadas para agirem em prol uns dos outros. Diante das acusações e denúncias, foram trinta e três respostas que demandaram serem ouvidas.

Fez-se quase uma assembleia escolar.

Isso mostra que a escola, também, é habitada pelo poder do coletivo que povoa corpos de alunos, que inventam mundos, abalam estruturas, que pensam ser muito firmes e sólidas. De repente, os alunos-alienígenas para muitos percebem que as forças coletivas não são algo dado ou ensinado pelo sistema de ensino, mas um desafio a ser conquistado. Provocam mudanças de postura e implicam consciência de pertencimento. Discutem, exigem, propõem e sugerem ações, atitudes e/ou soluções - de forma dialogada e com respeito - para problemas que compõem a escola.

Por fim, o questionamento persiste: estudar para quê? 


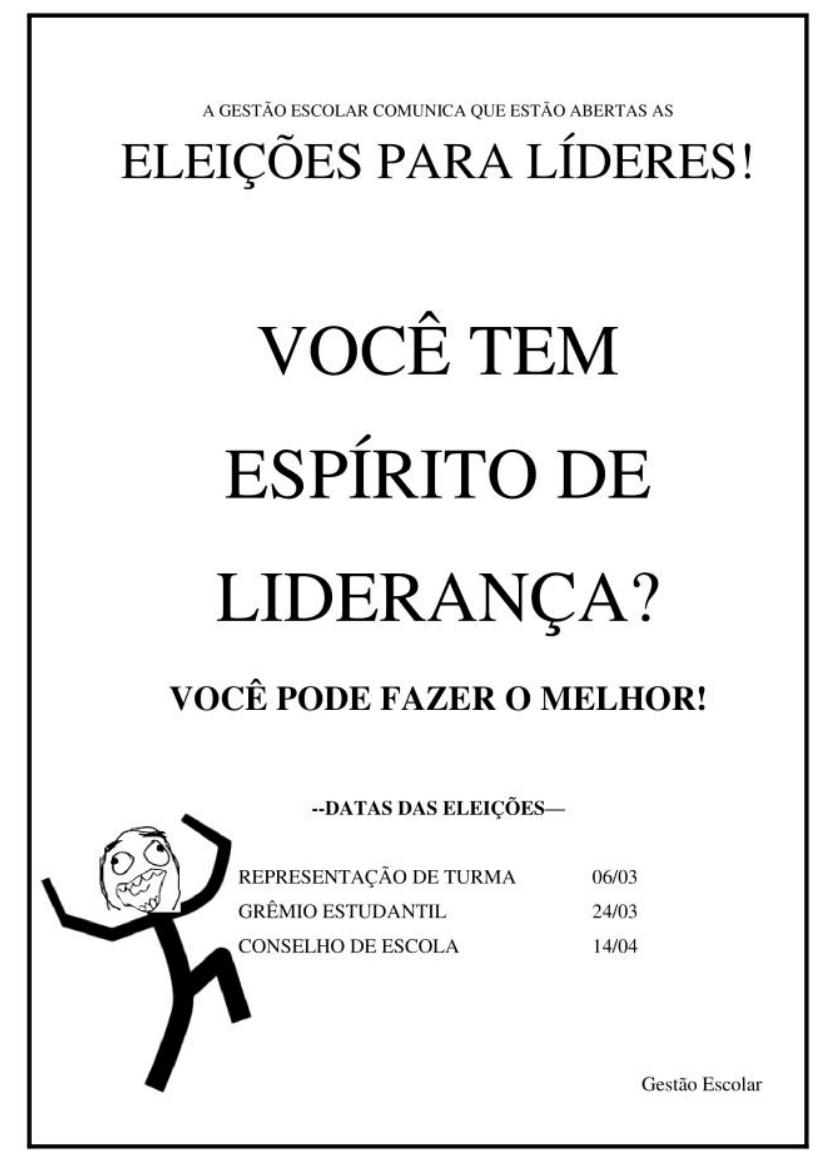

- Vocês viram o cartaz que a coordenadora espalhou pela escola?

- A chamada de líder de turma, né? Eu vi!

- Mas não é só líder de turma! Tem um monte de líder que eles estão querendo que a gente escolha... de turma, de grêmio, membros do conselho...

Eis, talvez, uma das saídas mais corriqueiras das escolas às mudanças repentinas de humores de estudantes: a criação dos famosos "líderes" das escolas. Líderes de turma, representantes dos Conselhos de Escola, chapas para o grêmio estudantil. Todos os modos de "liderança" e "representação" são evocados para apaziguar o tom das rebeldias, revoltas e insurreições estudantis. A escola há muito aprendeu a evitar problemas aproximando-se de alguns de seus rivais. A tática é muito bem ensinada, afinal, pela máquina capitalística que tenta se aproximar de tudo, valer-se de todos os seus discursos para, então, permanecer o devorador de mundo (LAZZARATO, 2014).

Para nosso infortúnio, também a escola tenta tal tática. 
Pelas escolas nas quais transitamos - somos professores da educação pública em três diferentes municípios do estado do Espírito Santo -, as turmas não demoram mais que um trimestre para fazer eleição dos famosos "líderes de turma". Fazendo leituras um pouco enviesadas da participação democrática presente nos documentos orientadores, algumas escolas fazem, logo no início, as tais escolhas. Assim, nascem os alunos que, de algum modo, acompanharão o trabalho da professora e serão a multiplicação de seus olhos e ordens.

Para muito, um posto privilegiado na cadeia de comando hierárquico.

Quando se fala dos líderes e representantes estudantis, todos os tipos de critério são válidos para a eleição. É comum, por exemplo, vermos alguns dos melhores alunos - quando não o melhor ou a melhor de todos! - ocupando esse cargo. Afinal, é um cargo de prestígio em sala e não deve ser dado a qualquer um! Ao mesmo tempo, entretanto, podemos também nos deparar com a jogada reversa, com a professora que se alia aos alunos mais terríveis em termos de bagunça. Jogada clássica, claro, de tentar controlar e atribuir a esses alunos certa responsabilidade para, então, amansar as feras.

Seja como for, entre os muitos tipos de jogadas possíveis, nós, professoras e professores, acabamos criando sempre essa imagem do aluno privilegiado, de alguém que, sob certas lógicas, merece está acima dos outros colegas e, portanto, possui certos direitos e regalias que outros nem sempre têm.

- Na nossa sala, é garantido que o Giumário Frederico vai se candidatar. Ele é representante todo ano...

- Quem não votaria nele? Ele é gaaaato! E ainda é sobrinho da diretora! Lembra que ano passado ele conseguiu até uma festa legal para a gente na semana dos alunos?

- Gato ele é! Mas não tô a fim de ver ele mais nisso, sabe? Na verdade, eu queria era que ninguém se candidatasse em turma nenhuma! Imagine a cara deles sem ninguém para eles falarem que "já conversamos com os alunos"?

- Verdade, né? Toda vez é a mesma coisa. Não podem ver um representante disso ou daquilo que só falam com eles. E depois, ainda, ficam se gabando que já ouviram a opinião da gente! Eu lá tenho cara de líder de turma? De presidenta do grêmio? Eu hein! A mim eles não ouviram!

Ora, talvez fosse esse justamente o ponto de ruptura necessário às nossas idealizações de liderança e representação. Não apenas o desejo de mudar as figuras representacionais, mas, para além disso, a necessidade de fazerem ruir tais forças e lugares de poder. 
Sob a ótica dos grupos anônimos que fizeram manifestos poderosos no último decênio - valemo-nos especificamente do Comitê Invisível (2016; 2017) e o Centelha (2019), dois grupos anônimos que publicaram no segundo decênio do século XXI manifestos filosóficos afirmando o caráter insurrecional das lutas contra o capitalismo -, vimos ser retomada uma discussão pertinente às filosofias anarquistas do século XX: e se não fossem necessárias representações? E se o poder pudesse ser implodido de dentro para fora e que todas as suas vísceras fossem expostas e arranjadas por todos os viventes?

Olhando o histórico recente das manifestações em nosso país, talvez pudéssemos ler justamente essa força anômala do anonimato insurgir nas ruas para rejeitar o caráter representacional das políticas e dos nossos modos de nos relacionarmos com os outros. Talvez pudéssemos ler as manifestações de junho de 2013, as reivindicações de escolas e hospitais padrões FIFA em 2014, as ocupações estudantis em 2016 e as passeatas em defesa da educação pública em 2019 nessa lógica anarquista de, diante dos ataques bem orquestrados dos governos, a melhor resposta possível é sumir em meio ao próprio movimento, tornar-se anônimo, rasgarse as feições pela sombra dos passos.

Se arremessam contra nós políticas de merda (COMITÊ INVISÍVEL, 2016), nossa melhor resposta é reagirmos em ações ainda mais vivazes. Se tentam nos controlar e incriminar, se tentam apontar dedos e rostos para enfraquecerem os movimentos, basta que cubramos nossas faces com interrogações, máscaras, capuzes, pinturas. Todos sabemos que, diante da engenharia governamental, aquele que for identificado sairá, involuntariamente, ou como uma vida desprezível ou como um aliado escondido.

- A turma do quarto ano, aquela do xixi na lixeira, resolveu indicar o Ferdinando para líder. Eu estava certa de que Zezinho não iria deixar, mas ele apoiou. E agora! O que eu faço? Aquele menino não presta. É muito atentado!

- Bem que eu te avisei para ter cautela naquela turma! Ano passado, no recreio, eles inventaram que queriam comer na sala pelo menos uma vez na semana. Zezinho ficou responsável por organizar o lanche compartilhado da semana, toda quinta.

- Ele é um amor! O Zezinho é tão educado, inteligente, organizado, sempre faz os deveres, um exemplo de aluno. E a mãe sempre vem nas reuniões. É o único momento em que eu aproveito para fazer elogios.

- Olha! Se você não quer o Ferdinando como representante da turma, fala com eles para não escolherem líder esse ano. Para resolverem as coisas na sala, todos juntos, conversando com você. Tente firmar diálogos com seus alunos. 
- Boa ideia! Vou tentar fazer isso. Pedirei para o Zezinho registrar as conversas. Ele é o que escreve melhor, então seria como se ele fosse o líder. Assim não teremos problema.

Quando escapamos do ideal de líder, do ideal de aluno, as manobras para contornar essas situações são inúmeras. A política representacional e o modelo de individualização da sociedade (LAZZARATO, 2011) ensina-nos a dar nomes, rostos e identidades a todos para melhor gerir os problemas e coroar com louros. O anonimato nos assusta: quem diz isso? Quem pergunta aquilo? Afinal, quem fez o que? Para contornar a multiplicidade amorfa, pensamos, por vezes, sermos mais espertos e conseguir, como professores, coordenadores e diretores, apontar para uma proposta que se aproxime do que almejamos como padrão, como limite para os alunos, principalmente os alunos-alienígenas.

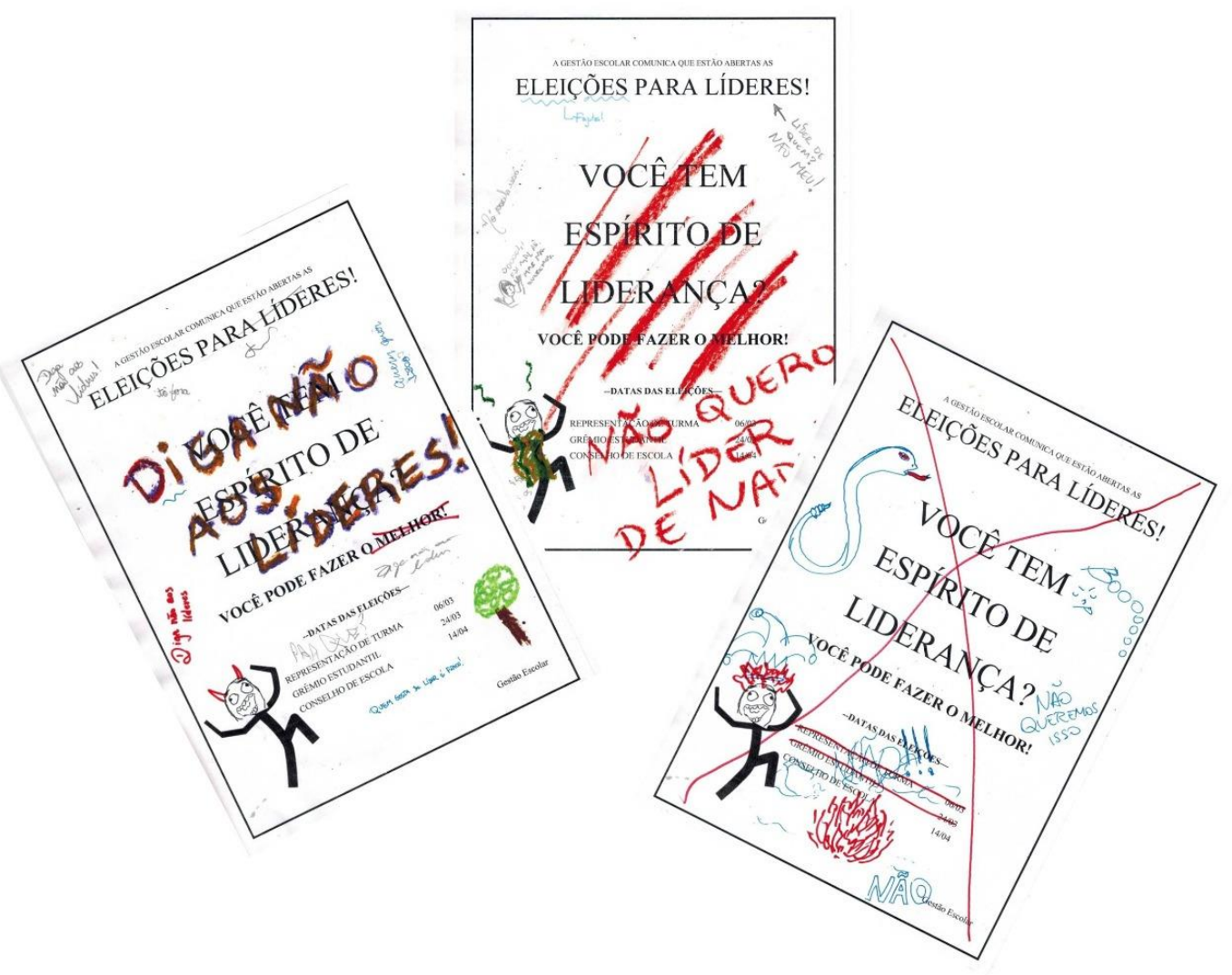

A professora acreditou ter encontrado a solução mais adequada para seu problema, mas antes que fizesse qualquer tentativa, os cartazes da escola já estavam todos pichados. Não se sabe como começou ou com quem - ou talvez até saibam, mas os danados falam um nome diferente a cada menção! -, mas eram canetinhas, canetas, lápis, giz de cera, tinta e rasgos por todos os cartazes. Em cada um deles, com os dizeres explícitos. "DIGA NÃO AOS LÍDERES". 
É. Parece que esse ano não vai ter eleição. Parece que a escola vai fazer parte de algum planeta ou satélite do sistema solar que não a Terra. Parece que temos uma escola-alienígena repleta de alunos-alienígenas, intrusos, que atravessam e percorrem outros sentidos, que não aceitam determinadas práticas enraizadas sem questioná-las.

O que fica explícito, na verdade, é que o "que se chama 'debate', em nossos dias, é apenas a morte civilizada da palavra" (COMITÊ INVISÍVEL, 2017, p. 72). Isto é, não há conversa. Aprendemos que o debate leva à concordância e, com isso, recusamos as intrigas, as discussões, as discordâncias. A política acaba se tornando a arte de gerir a mesmidade. A professora, esperançosa de um contexto em que poderia ludibriar seus alunos e acabar elegendo seu aluno ideal como representante, é atravessada por um gesto insurrecto que põe por terra a arma privilegiada das políticas de merda: o debate que, no fim, chega apenas a consensos, conversas e ideias, em que os alunos são meros expectadores.

Os estudantes sabem que, enquanto apenas debaterem, não conseguirão fazer outra coisa senão politicagens. Por isso, demonstram em atos a força coletiva de transformação. As rebeldias e insurreições demonstram que "o agir político não é uma questão de discurso, mas de gestos; e isso ele atesta justamente nas palavras que deixa com spray nos muros das cidades" (COMITÊ INVISÍVEL, 2017, p. 188), nas portas de banheiros, nos quadros entre intervalos, nas mesas das salas de aula.

Rompendo com todo o desejo de representação, eles rasgam as organizações que alegam as [frágeis] democracias e erguem-se em atos verdadeiramente coletivos, que deslocam a escola de seu lugar de conforto e estabilidade.

A imagem ideal de aluno, aquela do representante de turma e das perspectivas escolares enquadradas foi rasgada, ou melhor, pichada. Saímos de um padrão socialmente conduzido, das rotinas escolares, para algo que figura na zona de algazarra, algo que emerge no cotidiano escolar e revela ser, outrora, mais potente, algo perigoso e que não deveria servir de possibilidade de resposta à pergunta: "Estudar para quê?".

Aqui, todas imagens de escola, aluno e docências ruem.

É a engenharia escolar que é colocada abaixo em ações que tomam os pátios, pintam as paredes, picham os cartazes, exigem reuniões, ocupam a biblioteca, impedem a entrada, mijam nas lixeiras. As imagens dogmáticas das escolas - imagens estáticas acompanhadas de currículo meramente documentais - ruem porque, aqui, ganham vivacidade em suas movimentações. A escola, enquanto espaço demasiado projetado, há sempre de perceber que suas engrenagens, em algum momento, já pararam de girar com ela queria. 
Porque, enquanto ali for plenamente habitado (COMITÊ INVISÍVEL, 2016), toda a estrutura há de ruir.

Rui-se, então, com a rigidez de modelos pré-definidos, fixos, padronizados e determinados. As estruturas que enrijecem uma escola sofrem mudanças. E aqui entra de tudo, desde o famoso ensino mecânico até as múltiplas didáticas "legais" que visam apenas o desenvolvimento de índices escolares. As relações hierárquicas são sempre mantidas nesses contextos. E mesmo quando um professor ou outro são mais progressistas - "Faço questão que os representantes da minha turma participem ativamente nas tomadas de decisões da nossa sala!" -, ainda assim, caem na armadilha da liderança e representação.

É mesmo preciso que criemos esses espaços de representação tão regulados?

Na escola, é preciso que haja vidas e insurreições! Quiçá, vida alienígena! Espaço livre e sem controle para que os alunos, por meio da força da coletividade, sejam autores da própria ressignificação de suas experiências. Que vivenciem e construam outras possibilidades, para que, em comunidade, cada um possa ser parte do processo de criação de outros possíveis, outros mundos, outros conceitos, outras maneiras de habitar os espaços, outras relações.

Enfim, que aprendamos a sentir toda vida enquanto vida-alienígena.

\section{A escola insiste em se produzir: a fabulação não acaba}

Existe um aqui e agora que intensifica ainda mais a pergunta "Estudar para que?" quando, em momentos de pandemia, a escola precisa se reafirmar a cada reunião política, a cada documento exigido, a cada direcionamento rígido, a cada atividade remota entregue, a cada ordem de como justificar o trabalho não presencial da engenharia escolar. O aqui e agora se estende ad infinitum para que todos tomemos as medidas mais desesperadoras, mais drásticas como se fosse algo aceitável (CONSELHO NOTURNO, 2019).

A jogada capitalística é evidente: colocar os futuros em suspeição - a máquina capitalista parece gritar: "Um risco paira em nosso futuro! Precisamos evitar a catástrofe!" - ao mesmo tempo em que tentam assegurar um futuro prático com suas ameaças e propostas "Façamos isso e, enfim, poderemos todos sermos nós mesmos!".

O tempo do agora se torna uma ameaça contra todos nós - que, até então, apostávamos nas lutas no presente - pelo simples fato de que somos amarrados ao seu imperativo como reféns. 
A escola, que sempre foi alçada ao patamar de chave para o futuro, vê-se também na armadilha de quem limita os futuros. Afinal, os futuros compossíveis estão já limitados pelas forças capitalísticas há muito tempo.

Para preservar a vida, a escola pública se mantém firme na decisão de isolamento social e, paradoxalmente, é obrigada a recuperar o tradicionalismo no discurso do "novo normal". Tudo necessário para cumprir o currículo engessado ainda que usem hiperlinks e dispositivos de última geração. No ato, fabricam a imagem de aluno ideal super tecnológico que tem acesso ao que é requisitado para um processo de ensino e aprendizagem embasado no conteudismo.

Nesse novo jogo, retomam a imagem de um aluno totalmente conivente à hierarquia escolar, de um aluno ideal que além de autodidata é autocompetente e disciplinado, pois cumpre com todos os seus deveres. A nova roupagem supertecnológica e moderna mescla os espaços de casa e escola em uma onda tão massificante que os alunos e familiares não conseguem diferenciar os tempos de vida, de aprendizagem, de relações.

A família nunca esteve tão presente na escola quanto agora!

É difícil saber quem desgosta mais disso, se é a criança, o jovem, a escola ou a família em si.

A crítica de Paulo Freire (ALVIM; MAÇÃO; ROSEIRO, 2020) nunca foi tão contemporânea: confundem-nos com um depósito de saberes via acesso a plataformas, aplicativos ou apostilamentos. E pouco importa se somos alunos ou professores. A educação bancária parece mesmo ter ganhado mais força do que nunca.

Por isso, defendemos então a força fabulatória.

O texto conta com fabulações de escola que são, a um só tempo, reais e ficcionais (DELEUZE, 2013). Não que elas tenham acontecido tal qual confabulamos aqui! Decerto, não existem Escarlate das Graças e Gilmário Frederico enquanto tais. E, todavia, eles são forças presentes em todas as escolas.

Deveras o motivo deles aparecerem e, logo que começamos a leitura, reconhecemos suas existências, seus rostos, seus corpos como um daqueles que cruzamos todo dia em nossas escolas.

A fabulação, enquanto um modo de criação é sempre da ordem da resistência.

Fabular, no conceito deleuziano, articula o agora, o tempo presente, em uma ampliação dos tempos vindouros. Fabular exige uma falsificação do agora! Não que neguemos o tempo imediato, mas, antes, vemos os rastros quase imperceptíveis em nossas passagens pela vida.

Daí, justamente, surgem as fábulas. 
As histórias contadas sacodem as escolas enquanto lugar que aprisiona. Concordamos com Davis, Mação e Roseiro (2020) que as filosofias da educação, há muito, esqueceram-se das resistências e lutas estudantis. Preocupam-se tanto em dar finalidade às escolas, em discutir método e questões políticas que quase ignoram os corpos que vivem por ali.

Enquanto corpos curricularizados e curricularizantes, todos lutamos diariamente.

Lutamos por modos de educação menos dogmáticas, por relações mais horizontais, pelo reconhecimento de todos os corpos enquanto seres responsivos. Lutamos, em suma, por escolas que se engalfinhem, descaradamente, contra as amarras do tempo.

Fabulamos e, por isso mesmo, criamos vidas.

Fabulamos não apenas trechos do texto, mas as próprias possibilidades. Tudo o que dizemos são possibilidades iminentemente reais, porque trabalhamos na educação, vivenciamos esses contextos, falas e questionamentos o tempo inteiro. Nem por isso, todavia, são verdades absolutas. São tensões, ironias, risos. Gostaríamos que nossa escrita fosse lida com humor, que nos lançassem indagações. Escrevemos, conforme diria Deleuze (2013), com a força do falsário que esburaca a "verdade" com questões tão fajutas e tão surreais que nos fazem pensar nos limites do real. São fabulações... mas não dizem também de possibilidades do real?

Por isso, propomos nossa escrita como uma escrita de possibilidades. Quer dizer que os professores-engenheiros sempre reverenciam seus projetos-aulas como a deidade suprema? Queremos dizer que todo aluno-alienígena carrega consigo uma carga viral que incendiará as escolas com insurreições e resistências?

Evidentemente que não.

Todavia, ainda são possibilidades.

Talvez, quando todas as vidas forem tomadas enquanto alienígenas e finalmente conseguirmos enxergar as miudezas e as diferenciações com os estranhamentos, possamos dar conta de que não é necessário ser um professor-astronauta para tocar a vida alienígena sem exterminá-la. É, sim, possível fazer planejamentos mais elaborados, talvez até projetos mais engenhosos, e, todavia, sem que isso coloque o aluno-alienígena sob suspeição ou sob uma observação científica exterminadora.

Nossas escolas estão cheias de corpos em luta. Lutamos pela multiplicação das condições de vida. Fabulemos, pois, suas insurreições e rebeldias por todas as galáxias. 


\section{REFERENCIAS}

ALVIM, Davis Moreira; MAÇÃO, Izabel Rizzi; ROSEIRO, Steferson Zanoni. Ano 2091 silêncio nas filosofias da educação: por uma cartografia das resistências escolares. Educ. Pesqui., São Paulo, v. 46, e223171, 2020.

ALVIM, Davis Moreira; RODRIGUES, Alexsandro. Coletivos, ocupações e protestos secundaristas: a fênix, o leão e a criança. ETD - Educação Temática Digital, v. 19, n. Especial, p. 75-95, 2017.

CENTELHA. Ruptura. São Paulo: n-1 edições, 2019.

COMITÊ INVISÍVEL. Aos nossos amigos: crise e insurreição. Trad. Edições Antipáticas. São Paulo: n-1 edições, 2016.

COMITÊ INVISÍVEL. Motim e destruição agora. Trad. Vinícius Honesko. São Paulo: n-1 edições, 2017.

CONSELHO NOTURNO. Um habitar mais forte que a metrópole. Trad. Edições Qualquer. São Paulo: Glac Edições 2019.

DELEUZE, Gilles. A imagem-tempo: cinema 2. Trad. Eloísa Araújo Ribeiro. São Paulo: Brasiliense, 2013.

DELEUZE, Gilles; GUATTARI, Felix. Mil platôs: capitalismo e esquizofrenia 2, vol. 1. Trad. Ana Lúcia de Oliveira, Aurélio Guerra Neto e Célia Pinto Costa. 2. ed. São Paulo: Ed. 34, 2011a.

DELEUZE, Gilles; GUATTARI, Felix. O anti-Édipo: capitalismo e esquizofrenia 1. Trad. Luiz B. L. Orlandi. 2. ed. São Paulo: Ed. 34, 2011 b.

GUATTARI, Felix. Revolução molecular: pulsações políticas do desejo. Trad. Suely Rolnik. 2. ed. São Paulo: Brasiliense, 1985.

LAPOUJADE, David. Deleuze, os movimentos aberrantes. Trad. Laymert Garcia dos Santos. São Paulo: n-1 edições, 2015.

LAZZARATO, Maurizio. O governo das desigualdades: crítica da insegurança neoliberal. Trad. Renato Abramowicz Santos. São Carlos: EdUFSCar, 2011.

LAZZARATO, Maurizio. Signos, máquinas, subjetividades. Trad. Paulo Domenech Oneto e Hortência Lencastre. São Paulo: n-1 edições; Edições Sesc São Paulo, 2014.

NIETZSCHE, Friedrich. Além do bem e do mal. Trad. Carlos Duarte e Anna Duarte. São Paulo: Martin Claret, 2015.

NOGUERA-RAMÍREZ, Carlos Ernesto. Pedagogia e governamentalidade ou Da

Modernidade como uma sociedade educativa. Belo Horizonte: Autêntica Editora, 2011. 
SAVIANI, Demerval. Pedagogia histórico-crítica: primeiras aproximações. 11. ed. Campinas: Autores Associados, 2013.

\footnotetext{
${ }^{\text {i }}$ Professor da Rede Municipal de Ensino de Cariacica/ES e doutorando no Programa de Pós-Graduação em Educação da Universidade Federal do Espírito Santo. Prefeitura Municipal de Cariacica/ES - Brasil. Lattes: http://lattes.cnpq.br/5342221323204014 . ORCID iD http://orcid.org/0000-0003-1424-2281

ii Professor da Rede Municipal de Ensino de Viana/ES e mestrando pelo Programa de Pós-Graduação em Educação pela Universidade Federal do Espírito Santo. Prefeituras Municipal de Viana/ES - Brasil. ORCID iD http://orcid.org/0000-0002-5684-0880

iii Professora da Educação Infantil da Rede Municipal de Ensino de Serra/ES e mestra pelo Programa de Pós-

Graduação em Educação pela Universidade Federal do Espírito Santo. Prefeitura Municipal de Serra/ES - Brasil. ORCID iD https://orcid.org/0000-0002-9725-7755
}

iv Ao longo do texto, optamos por manter o termo aluno ou aluna, apesar de possível repetição. Temos apostado em tal termologia por vermos, diante da conjuntura neoliberal, a insistência pelo uso estudante. Conforme sugere Carlos Ernesto Noguera-Ramírez (2011), todos os corpos colocam-se em situação de aprendizado permanente nesse contexto neoliberal e todos aprendem continuamente. Assim, ressaltamos o caráter de aluno e aluna para falar dos corpos específicos da instituição escolar. 